\title{
Integrating Multiple Intelligences and Technology into Classroom Instruction to Transform Instructional Practice in Malaysia
}

\author{
Tajularipin Sulaiman \\ University Putra Malaysia \\ Suriati Sulaiman \\ Faculty of Educational Studies, University Putra Malaysia \\ Wei Hui Suan \\ Centre for Foundation Studies and Extension Education, Multimedia University, Cyberjaya. Malaysia \\ Email: hswei@mmu.edu.my
}

\begin{abstract}
Approaching curriculum content through multiple entry points and integrating technology into classroom instruction which will help the educational system achieves the National Philosophy of Education to meet the challenges of the $21^{\text {st }}$ century. Thus, there is a need for a procedural model that could help teachers modify their lesson to address the student's intelligence by integrating multiple intelligences and instructional technology into classroom instruction. This paper provides an overview of the POMAT approach that gives due attention to a lesson's procedure includes instructional activities, objective or learning outcome, materials, assessment, and instructional technology in classroom instruction. It involved a step-by-step process of modifying the existing lesson and integrating multiple intelligences and technology into instruction. The process breaks up the lesson plan process into five steps that require teachers to think about how well their lesson maps out. Using this approach, teachers should look at a lesson's procedure first, and then maps back through the objective, materials, assessment, and technology to determine a consistency of purpose. The actual flow of a lesson should nicely match the objective, materials, assessment and technology. The entire procedure is designed to examine a lesson's consistency within the context of the eight intelligences.
\end{abstract}

Index Terms-instructional technology, multiple intelligences, instructional practice, classroom instruction

\section{INTRODUCTION}

Many initiatives have been implemented to transform Malaysian educational system, in line with and in support of the nation's effort to fulfil Vision 2020. The Vision aims for sustained, productivity-driven growth which will be achievable only with a technologically literate, critically thinking work force prepared to participate fully in the global economy of the $21^{\text {st }}$ century. At the same time, Malaysian National Philosophy of Education calls for developing the potential of individuals in a holistic and integrated manner so as to produce individuals who are intellectually, spiritually, emotionally, and physically balance and harmonious. According to Malaysian Smart School Conceptual Blueprint (1997), this massive transformation includes individualizing the education, approaching curriculum content through multiple entry points and integrating technology into classroom instruction which will help the educational system achieves the Vision 2020 and National Philosophy of Education, while fostering the development of a work force prepared to meet the challenges of the $21^{\text {st }}$ century. Thus, there is a need for a procedural model that could help teachers modify their lesson to integrate multiple intelligences and instructional technology into classroom instruction.

\section{TheORY OF MULtiPLE InTELLIGENCES IN TRANSFORMing MALAYSIAN EdUCATIONAL SySTEM}

Transforming the present educational system entails changing the culture and practice of Malaysian primary and secondary schools. The transformation will move away the educational system from memory-based learning, designed for the average students to an education, which stimulates thinking, creativity and caring in all students, caters to individual abilities and learning styles, and is based on more equitable access. Furthermore, the new educational system requires students to exercise greater responsibility for their own education.

Such transformation also demands the teachers to review their style of teaching and to integrate technology into their classroom instruction. Nowadays, instructional technology particularly the use of computer, software, and internet application has became so widespread in schools and their uses have expanded dramatically that many teachers now think about its implications on instructional practices. Instructional technology has brought about changes in the instructional methodologies. In teaching a second language such as English Language and Mandarin, any language support is helpful 
for language acquisition. Language students need a variety of language experiences. They need to hear language, write language, speak language and read language. Computers, software and internet application are believed can play an integral part in providing the language students with valuable and diverse language experiences. Thus, instructional technology can be an asset to transform instructional practice in Malaysia.

In addition to that, transforming the present educational system calls for integrating multiple intelligences that reflects so much of Gardner's (1993, and 2004) multiple intelligences theory into instructional practice. Multiple intelligences teaching approach (MITA) provides teachers an opportunity to teach in a variety of ways and reach students all the way regardless of students' different abilities and interests (Shearer, 2009). Gardner's theory of multiple intelligences (MI) confirms so much of the work teachers have already done in the classroom (Mckenzie, 2005). In fact, good teachers have been instinctively catering to different intelligences without even knowing of the multiple intelligences model (Mckenzie, 2005).

In many ways, the lessons which are designed to incorporate multiple intelligences and technology do meet the needs of various learning styles (Rosen, 1997). Furthermore, teaching through intelligences has been found to increase interest and achievement in classroom assessment (Campbell \& Campbell, 1999; Greenhawk, 1997; Kornhaber, Fierros, \& Veenema, 2003). In addition to that, teaching with technology has been found to improve vocabulary, fluency, comprehension and grammar skills (Case \& Truscott, 1999; Lewis, 1997). Most of the instructional activities based on multiple intelligences theory had a good effect on the students and improved their achievement (Yilmaz \& Fer, 2003). Multiple intelligences theory has positive effects on students and teachers and helped teachers recognize that all students have different intelligence profiles and improved classroom environment and students achievement (Saban, 2000).

\section{MODIFYING EXISTING LESSON}

In order to transform the present instructional practice, teachers should consider modifying the existing lesson. Teachers should revise their instructional practice such as the use of textbooks. For the last half-century, teachers have relied on textbook that put together pre-packaged curriculum instructional programs and serves as primary source of knowledge to classroom instruction. Teachers are accustomed to having a textbook in place that they can borrow from and refer to as needed. Having a textbook is convenient and it saves teachers' time to produce instructional and learning materials too. Moreover, it is familiar after five decades and it is comfortable. However, simply using a textbook, which is assumed by many teachers to be an appropriate instructional material for instruction, could be questioned of its effectiveness in teaching and learning process nowadays (Mckenzie, 2005).

Multiple intelligences theory on the other hand recognizes the unique nature of each individual student. Developing lessons based on this theory requires a blend of the teacher's personal instructional style with the particular combination of student multiple intelligences profiles present in any given class. Undeniably some teachers, who are interested incorporating multiple intelligences theory into their instruction, have some uncertainty of whether they have to revise their objectives, or how they could decide on which intelligences to employ in their lesson, or whether they have to incorporate all the intelligences into a lesson (Mckenzie, 2005).

Definitely there is no one right answer to each question. However, teachers should edit and revise existing lessons with the idea of maximizing the number of intelligences accommodated. This should not be an exercise in documenting the intelligences that the lessons already address. To simply categorize existing lessons by the intelligences they accommodate is to spend time revising the lessons teachers intend to change. Making modifications based on multiple intelligences is to take lessons teachers already know and love and improve them by making additional connections for all their students.

Yet teachers should understand what it means to accommodate, stimulate, or employ the intelligence in a lesson. In this context, exercising the intelligence means that an activity utilizes that intelligence for the explicit purpose of instruction. For example, students talk with one another while completing a writing assignment does not demonstrate that they are exercising their interpersonal intelligence. This is because talking while doing the assignment does not support the instructional objective. On the other hand, having students work together to brainstorm possible solutions as part of a creative problem-solving activity contributes to the learning outcome of the lesson. It is by definition an accommodation of the interpersonal intelligence. An apparent example is in Gardner's humorous anecdote when he visited a kindergarten classroom, where he observed children crawling on their hands and knees, yelping and howling (Mckenzie, 2005). When he asked the teacher about the activity, Gardner was informed that the children were exercising their kinaesthetic intelligence. Unimpressed, Gardner responded that the activity did not stimulate kinaesthetic intelligence. In fact, the children were merely crawling on the floor and howling like wolves.

Teachers should bear in mind that it is not necessary or even advisable to try to accommodate all the intelligences in any one lesson (Mckenzie, 2005). Trying to work all intelligences into a single lesson usually results in an unnatural learning environment, with students unable to benefit from saturation of inputs and experiences. Instead, teachers should expect to integrate not more than three to five intelligences into one lesson (Mckenzie, 2005). The most appropriate intelligences to target will become more evident as teachers work with an existing lesson and should flow naturally from the content of their plan. This is important because students need to see natural, obvious connections between the intelligences if they are going to truly benefit from teachers efforts. If a lesson tries to force a musical connection that just does not flow with the rest of the lesson, it will throw students off rather than help them understand. In short, if 
the introduction of a new intelligence into an existing lesson does not fit naturally and easily into the plan, teachers should omit it.

Designing a multiple intelligences lesson that incorporates technology into classroom instruction requires teachers to start with a clear educational objective as proposed in Bloom's taxonomy of educational objectives for cognitive domain (see Table 1) which later had been revised as a new version (Anderson \& Krathwohl, 2001). Benjamin Bloom has introduced six progressively complex steps of cognitive development. He offered teachers a rubric for developing instructional objectives at increasingly advanced levels of higher-order thinking. The taxonomy is considered among the most practical theories of instructional and learning (Tomei, 2003). Creating instructional objectives requires teachers to identify specific objectives for learning outcomes. For example, teachers may note the learning outcome as by the end of the Science lesson as, students should be able to define photosynthesis. Teachers may shift the level of cognitive development from the first level of knowledge to the highest level of creating from one lesson to another lesson (see Table 1).

Teachers should continually refer back to the objective to make sure that they are staying on their primary objective as they build the rest of the lesson. For an existing lesson, this may mean modifying the original objective slightly to make room for additional learning outcomes. With a clear objective in place, teachers could then identify the intelligences they want to include in their lesson. There should be an obvious, natural connection between any intelligence that they choose to include and the objective. Besides, teachers should use the objective and list of intelligences to determine the technology that they would like to employ in the lesson. Not every lesson will benefit from the use of instructional technology, and knowing when it is and is not appropriate comes with practice and experience. As teachers start the process of modifying lessons, their purpose is to help students reach the stated objective by incorporating technology that stimulates the target intelligences.

In integrating technology into instruction teachers should carefully consider which instructional technology (see Figure 1) might be the most appropriate to be incorporated into their lesson. Technology should only be chosen if and when it enhances student learning. In Malaysian context, the technology varies from modules for computer-assisted instruction, tools, network-based, to application software (Ministry of Education, 1997). For instance, animation software clearly encourages spatial intelligence. If teachers wish to bolster the visual element in their lesson, animation software will be a good choice. Spreadsheet software is great for stimulating the logical intelligence and for making connection to the spatial intelligence with a graph or chart. If teachers would like to reinforce the spatial and logical intelligences, spreadsheet program is clearly a good choice. Presentation software makes excellent use of the verbal, spatial, and interpersonal intelligences. Teachers can also bring in the musical intelligence, if that is appropriate for their students. In short, teachers are the one who can determine the most pertinent instructional technology for their lesson (See Figure 1).

Anyway teachers have to emphasize on the context for their lesson to determine the technology that is right for them (Mckenzie, 2005). They can decide either not to use technology to keep the lesson finite and circumscribed, or to add non-technological tasks including oral presentation, or a discussion to the lesson to stimulate additional intelligences. They can use animation software or spreadsheet software to enhance the lesson objective, or to use multimedia presentation software to extend the lesson without changing its primary focus, or to choose an online collaborative project and develop a lesson to be in a completely new direction that opens it up to a variety of intelligences.

\section{USING POMAT APPROACH}

To make it easier to move from theory to practice, the POMAT approach, a procedural model for modifying existing lessons was developed by Walter Mckenzie (2005). This approach gives due attention to a lesson's procedure includes instructional activities, objective or learning outcome, materials, assessment, and instructional technology in classroom instruction. Teachers might find that after creating a few lessons in this way it is easy to fall into a pattern of using similar-sounding objectives with familiar intelligences and appropriate technology applications, lesson after lesson. The POMAT process breaks up the lesson plan process into five steps that require teachers to think about how well their lesson maps out. This approach is a step-by-step process of modifying the existing lesson and integrating multiple intelligences and technology into instruction.

Using this approach, teachers should look at a lesson's procedure first, and then maps back through the objective, materials, assessment, and technology to determine a consistency of purpose. The actual flow of a lesson should nicely match the objective, materials, assessment and technology. If the lesson is inconsistent in any of its critical components, the POMAT process will identify gaps and weakness that teachers can address later. The entire procedure is designed to examine a lesson's consistency within the context of the eight intelligences.

The POMAT process involves five steps. First of all, without looking at any other part of the existing lesson, teachers should go directly to the lesson's procedure and make some notes on each prescribed activity and the intelligences it accommodates. For example, if students are asked to listen to a short story, teachers may note the verbal-linguistic intelligence on the POMAT chart (see Table 2). If students are then asked to draw a mind map, teachers may note on the POMAT chart that this stimulates the visual-spatial intelligence. Teachers should complete this process for the entire lesson's procedure, noting any and all intelligences that are accommodated (see Table 2).

The next step is teachers should go to the beginning of the lesson plan and examine their stated objective or learning outcome (LO). Teachers will note on the POMAT chart which intelligences seem to fit this learning outcome. For in- 
stance, if the learning outcome states that by the end of the lesson, students should be able to write a plot of the short story in five paragraphs in groups, teachers may note that it will accommodate the verbal-linguistic and interpersonal intelligences. However, teachers must make sure that they note only the intelligences the learning outcome clearly accommodates.

Then, with the procedure and learning outcome reviewed, teachers should now look at the list of materials they have generated for the lesson and identify which intelligences these materials stimulate. Teachers may note on the POMAT chart that the text book, graphic organizer and mind map may stimulate verbal, visual spatial and logical-mathematical intelligences.

After that, teachers should look at their assessment plan. It should be consistent with the procedure, learning outcome, and materials in the intelligences it utilizes. There should be a clear agreement between procedure, learning outcome, materials, and assessment in terms of the intelligences addressed. In the case of testing students' understanding of the plot of the short story, quiz is the best of choice. It is practical and relevant for the lesson. If the assessment matches well with the objective and the intelligences that have been identified throughout the lesson, teachers are on the right track.

Finally, teachers should review the POMAT chart that they have created and determine which technology, if any, should be included in the lesson. Most likely teachers are already employing certain instructional technology in the lesson. Since teachers intend to integrate technology into classroom instruction, they might think of digital technology to be included in the lesson. They may project a slide on the wall and decide that it will be an appropriate use of technology. Or teachers might use a desktop publishing programme so that the class can work on a creative writing and produce a brochure. With sufficient planning, teachers can even invite other classes to participate in a competition to meet the learning outcome, and compare results. The lesson which fits in the overall curriculum will determine which uses of technology are most appropriate and effective.

An advantage of analyzing the existing lesson using the POMAT method is it will help teachers quickly identify areas of strength in their lesson. Teachers could see a clear intelligence dimension to the learning task, learning outcomes, materials, assessment and instructional technology. Eventually, the lesson will cater differing needs and abilities of all students in the class. Besides, if it happened that teachers have a significant number of students who are dominant in certain intelligences, they may consider modifying the learning outcome and procedures accordingly. Teachers may do so easily and at once by using the POMAT method.

\section{IMPLICATION OF INTEGRATING TECHNOLOGY INTO MI CLASSROOM INSTRUCTION}

With the implementation of new instructional strategies, teachers should not simply rely on the textbook. It becomes their main priority now to design instructional materials that take into account students' multiple intelligences. These materials will accommodate students differing needs and abilities, resulting in fuller realisation of their capabilities and potential, and allow students to take greater responsibility for managing and directing their own learning. To ensure that all materials are fit to be used teachers should refer to conceptual selection and evaluation guidelines for teaching and learning materials (see Table 3) that cover five main criteria namely instruction adequacy, technical adequacy, curriculum adequacy, cost effectiveness, and cosmetic adequacy (Ministry of Education, 1997) (See Table 3).

Furthermore, teachers should consider diverse individual student intelligence profiles in designing and recommending instructional methods and technology (see Table 4) for the whole class (Armstrong, 2000; Ministry of Education, 1997). For example, for students who are strong in verbal linguistic, teachers could design a lesson that incorporates creative writing and ask them to produce a brochure using a desktop publishing programme (See Table 4).

However, conventional media, commonly used in today's educational settings, can still feature in the lesson (Ministry of Education, 1997). Basically, it is classified into three main categories namely printed media, 3D objects, and audio visual media (see Table 5). On the other hand, there is no harm if teachers want to use conventional media in an integrated manner with technology as long as it will help teachers achieve their learning outcome (See Table 5).

Integrating technology into classroom instruction seeks the teachers to acquire teaching and learning materials from a wide range of sources, and will no longer be limited by resources within schools (see Figure 2). In addition to libraries, businesses, homes, government departments, other sources of teaching and learning materials include edunet, internet and classified printed directories (Ministry of Education, 1997). In this case, teachers can surf the internet to get teaching and learning materials and adapt or adopt it to match it with their learning outcome and their students' differing needs and abilities (See Figure 2).

\section{CONCLUSION}

If teachers believe that technology is just another tool for instruction, then it is worth no more than any other piece of equipment in their classrooms. The true potential of instructional technology could only be seen if teachers are willing to let go of their preconceived notions and traditional ideas. Thus, teachers need to allow technology to transform their classrooms for the Information Age. It will never too late for teachers to consider accommodating several intelligences through different instructional technology and media in their lesson. However, to integrate multiple intelligences and technology into instruction, teachers must aspire to become a techno-constructivist (Mckenzie, 2005). As for a techno- 
constructivist, technology is not merely an instructional tool in fact it is a way to transform the classroom into a new and vital learning environment for students. Only at this level teachers could truly realize the full potential of every student in their charge.

In a nutshell, integrating technology and multiple intelligences into English classroom instruction not only individualizes the education and approaches curriculum content through multiple entry points but also encourages students to take control of their own learning and persuades teachers to be a techno-constructivist which would transform the present instructional practice in Malaysia.

\section{APPENDIX:}

TABLE 1:

REVISED VERSION FOR BLOOM'S TAXONOMY OF COGNITIVE DOMAIN

\begin{tabular}{|c|c|c|c|}
\hline LEVEL & DEFINITION & $\begin{array}{l}\text { SAMPLE } \\
\text { VERBS }\end{array}$ & $\begin{array}{l}\text { SAMPLE } \\
\text { OBJECTIVES }\end{array}$ \\
\hline REMEMBERING & 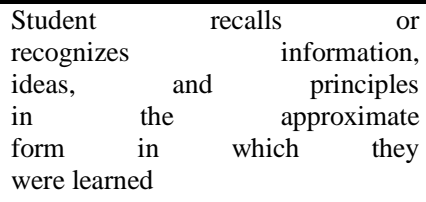 & $\begin{array}{l}\text { Write } \\
\text { List } \\
\text { Label } \\
\text { Name } \\
\text { State } \\
\text { Define }\end{array}$ & \begin{tabular}{llr}
\multicolumn{2}{l}{ Students should be } \\
able $\quad$ to & define \\
the $\quad 6 \quad$ levels of & Bloom's \\
taxonomy & of & the \\
cognitive domain & &
\end{tabular} \\
\hline UNDERSTANDING & $\begin{array}{lrr}\begin{array}{l}\text { Student } \\
\text { comprehends, }\end{array} & \text { translates, } \\
\text { interprets } & & \text { or } \\
\text { based } & \text { on } & \text { information } \\
\text { learning } & & \text { prior }\end{array}$ & $\begin{array}{l}\text { Explain } \\
\text { Summarize } \\
\text { Paraphrase } \\
\text { Describe } \\
\text { Illustrate }\end{array}$ & $\begin{array}{l}\text { Students should be } \\
\text { able to } \\
\text { the purpose of } \\
\text { taxonomy } \\
\text { cognitive domain }\end{array}$ \\
\hline APPLYING & $\begin{array}{lrr}\text { Student } & & \text { translates, } \\
\text { comprehends, } & & \text { or } \\
\text { interprets } & & \text { information } \\
\text { based } & \text { on } & \text { prior } \\
\text { learning } & & \end{array}$ & $\begin{array}{l}\text { Use } \\
\text { Compute } \\
\text { Solve } \\
\text { Demonstrate } \\
\text { Apply } \\
\text { Construct }\end{array}$ & 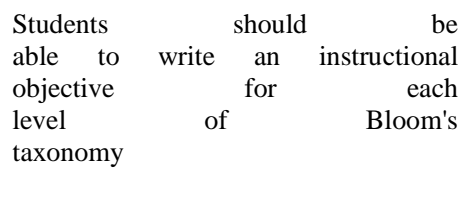 \\
\hline ANALYZING & $\begin{array}{l}\text { Student distinguishes, } \\
\text { classifies, and relates the assump- } \\
\text { tions, } \\
\text { hypotheses, evidence, or structure of } \\
\text { a } \\
\text { statement or question }\end{array}$ & $\begin{array}{l}\text { Analyze } \\
\text { Categorize } \\
\text { Compare } \\
\text { Contrast } \\
\text { Separate }\end{array}$ & $\begin{array}{l}\text { Students should } \\
\text { able to compare and } \\
\text { contrast the cognitive } \\
\text { and affective domains }\end{array}$ \\
\hline EVALUATING & $\begin{array}{l}\text { Student appraises, } \\
\text { assesses, or critiques on a basis of } \\
\text { specific standards and criteria }\end{array}$ & $\begin{array}{l}\text { Judge } \\
\text { Recommend } \\
\text { Critique } \\
\text { Justify }\end{array}$ & $\begin{array}{l}\text { Students should be able to judge the } \\
\text { effectiveness of writing objectives } \\
\text { using Bloom's taxonomy }\end{array}$ \\
\hline CREATING & $\begin{array}{l}\text { Student } \\
\text { integrates, originates, } \\
\text { combines ideas into a product, plan } \\
\text { or proposal that is new to him or her }\end{array}$ & $\begin{array}{l}\text { Create } \\
\text { Design } \\
\text { Hypothesize } \\
\text { Invent } \\
\text { Develop }\end{array}$ & 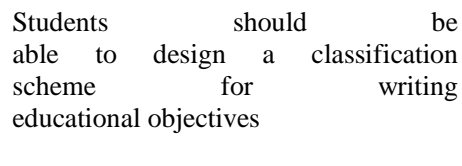 \\
\hline
\end{tabular}




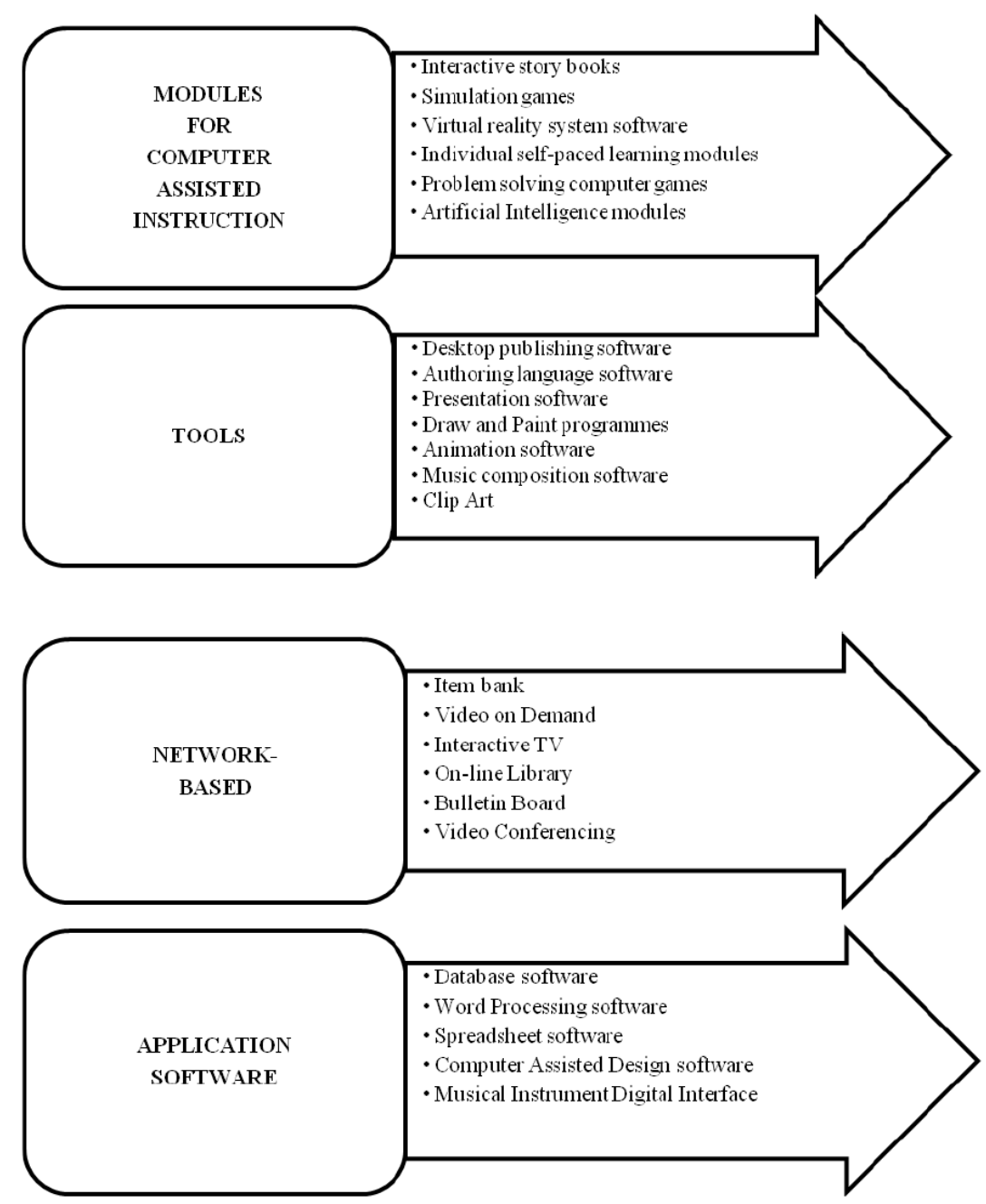

Figure 1: Instructional Technology

TABLE 2:

THE POMAT CHART

\begin{tabular}{|c|c|c|c|c|c|}
\hline Intelligences & Procedure & Objective & Materials & Assessment & Technology \\
\hline Linguistic & $\checkmark$ & $\checkmark$ & $\checkmark$ & $\checkmark$ & $\checkmark$ \\
\hline $\begin{array}{l}\text { Logical- } \\
\text { Mathematical }\end{array}$ & & & $\checkmark$ & $\checkmark$ & \\
\hline $\begin{array}{l}\text { Spatial } \\
\text { Musical }\end{array}$ & $\checkmark$ & & $\checkmark$ & $\checkmark$ & $\checkmark$ \\
\hline $\begin{array}{l}\text { Interpersonal } \\
\text { Intrapersonal }\end{array}$ & $\checkmark$ & $\checkmark$ & & & $\checkmark$ \\
\hline \multicolumn{6}{|l|}{$\begin{array}{l}\text { Bodily- } \\
\text { Kinaesthetic } \\
\text { Naturalist }\end{array}$} \\
\hline NOTES & $\begin{array}{l}\text { Read the story, } \\
\text { Listen to the story, } \\
\text { Draw a mind map, } \\
\text { Present to class } \\
\text { Work in groups }\end{array}$ & $\begin{array}{l}\text { Write a plot of the story } \\
\text { in five paragraphs }\end{array}$ & $\begin{array}{l}\text { Text book, } \\
\text { Mind Map, } \\
\text { Graphic Organ- } \\
\text { izer }\end{array}$ & Quiz & $\begin{array}{l}\text { Microsoft Power- } \\
\text { Point, } \\
\text { Microsoft Word }\end{array}$ \\
\hline
\end{tabular}


TABLE 3:

COMPONENTS OF QUALITY MATERIAL

\begin{tabular}{|c|c|}
\hline CRITERIA & FEATURES \\
\hline INSTRUCTION ADEQUACY & $\begin{array}{l}\text { - Promotes vertical and horizontal } \\
\text { integration } \\
\text { - Considers different capabilities of } \\
\text { students and teachers } \\
\text { - Suitable for a variety of learning } \\
\text { environments } \\
\text { - Well designed interface } \\
\text { - Professionally done } \\
\text { - Adaptable to different instructional-learning } \\
\text { styles }\end{array}$ \\
\hline TECHNICAL ADEQUACY & $\begin{array}{l}\text { - User-friendly } \\
\text { - Clear and comprehensive manuals and } \\
\text { guides }\end{array}$ \\
\hline CURRICULUM ADEQUACY & $\begin{array}{l}\text { - In-line with curriculum specifications } \\
\text { - Promotes values, skills (especially } \\
\text { thinking skills), knowledge, and language } \\
\text { across the curriculum } \\
\text { - Consistent with instructional-learning } \\
\text { objectives } \\
\text { - Content is accurate and up-to-date } \\
\text { - Content is relevant to student's } \\
\text { environment } \\
\text { - Assessment is built-in }\end{array}$ \\
\hline COST EFFECTIVENESS & - Value for money \\
\hline COSMETIC ADEQUACY & $\begin{array}{l}\text { - Graphic quality } \\
\text { - Video quality } \\
\text { - Animation quality } \\
\text { - Voice \& sound quality } \\
\text { - Layout quality } \\
\text { - Colour and fonts quality }\end{array}$ \\
\hline
\end{tabular}

TABLE 4:

INSTRUCTIONAL METHODS AND TECHNOLOGY

\begin{tabular}{|c|c|c|}
\hline INTELLIGENCE PROFILES & INSTRUCTIONAL METHODS & INSTRUCTIONAL TECHNOLOGY \\
\hline VERBAL/LINGUISTIC & $\begin{array}{l}\text { - Reading } \\
\text { - Vocabulary } \\
\text { - Formal Speech } \\
\text { - Journal/Diary Keeping } \\
\text { - Creative Writing } \\
\text { - Poetry } \\
\text { - Verbal Debate } \\
\text { - Impromptu Speaking } \\
\text { - Humour/Jokes } \\
\text { - Storytelling }\end{array}$ & $\begin{array}{l}\text { - Word processing } \\
\text { programmes } \\
\text { - Typing tutors } \\
\text { - Desktop publishing } \\
\text { programmes } \\
\text { - Electronic libraries } \\
\text { - Interactive } \\
\text { storybooks } \\
\text { - Word Games }\end{array}$ \\
\hline LOGICAL/MATHEMATICAL & $\begin{array}{l}\text { - Abstract } \\
\text { Symbols/Formulas } \\
\text { - Outlining } \\
\text { - Graphic Organisers } \\
\text { - Number Sequences } \\
\text { - Calculation } \\
\text { - Deciphering Codes } \\
\text { - Forcing Relationships } \\
\text { - Syllogisms } \\
\text { - Problem-Solving } \\
\text { - Pattern Games }\end{array}$ & $\begin{array}{l}\text { - Mathematical skills } \\
\text { tutorials } \\
\text { - Computer } \\
\text { programming } \\
\text { tutors } \\
\text { - Logic games } \\
\text { - Science programmes } \\
\text { - Critical thinking } \\
\text { programmes }\end{array}$ \\
\hline VISUAL/SPATIAL & $\begin{array}{l}\text { - Visualisation } \\
\text { - Active Imagination } \\
\text { - Colour Schemes } \\
\text { - Patterns/Designs } \\
\text { - Painting } \\
\text { - Drawing } \\
\text { - Mind-mapping } \\
\text { - Pretending } \\
\text { - Sculpture } \\
\text { - Visual Pictures }\end{array}$ & $\begin{array}{l}\text { - Animation } \\
\text { programmes } \\
\text { - Draw and Paint } \\
\text { programmes } \\
\text { - Electronic chess } \\
\text { games } \\
\text { - Spatial problem } \\
\text { solving games } \\
\text { - Electronic puzzle } \\
\text { kits } \\
\text { - Clip Art } \\
\text { programmes }\end{array}$ \\
\hline
\end{tabular}




\begin{tabular}{|c|c|c|}
\hline & & $\begin{array}{l}\cdot \text { - Geometry } \\
\text { programmes } \\
\text { - Graphic } \\
\text { presentations of } \\
\text { knowledge }\end{array}$ \\
\hline \multirow[t]{10}{*}{ BODY/KINESTHETIC } & - Folk/Creative Dance & • Hands-on \\
\hline & • Role Playing & construction kits \\
\hline & - Physical Games & that interface with \\
\hline & - Drama & computers \\
\hline & • Martial Arts & • Motion-simulation \\
\hline & • Body Language & games \\
\hline & - Physical Exercise & - Virtual-reality \\
\hline & $\begin{array}{l}\text { - Mime } \\
\text { - Inventing }\end{array}$ & system software \\
\hline & - Inventing & $\begin{array}{l}\text { Eye-hand co- } \\
\text { ordination games }\end{array}$ \\
\hline & & $\begin{array}{l}\text { - Tools that plug into } \\
\text { computers }\end{array}$ \\
\hline \multirow[t]{12}{*}{ MUSICAL/RHYTHMIC } & • Rhythmic Patterns & - Music literature \\
\hline & - Vocal Sounds/Tones & tutors \\
\hline & • Music & - Singing software \\
\hline & Composition/Creation & (transforms \\
\hline & - Percussion Vibrations & voice input into \\
\hline & • Humming & synthesiser sounds) \\
\hline & - Environmental Sounds & - Composition \\
\hline & • Singing & software \\
\hline & - Tonal Patterns & - Tone recognition \\
\hline & - Music Performance & $\begin{array}{l}\text { and melody memory } \\
\text { enhancers }\end{array}$ \\
\hline & & • Musical instrument \\
\hline & & $\begin{array}{l}\text { digital interfaces } \\
\text { (MIDI) }\end{array}$ \\
\hline \multirow[t]{13}{*}{ INTERPERSONAL } & - Giving Feedback & • Electronic bulletin \\
\hline & • Intuiting Others' & boards \\
\hline & Feelings & - Simulation games \\
\hline & - Co-operative Learning & \\
\hline & Strategies & \\
\hline & - Person-to-Person & \\
\hline & $\begin{array}{l}\text { Communication } \\
\text { - Emnathy Practices }\end{array}$ & \\
\hline & $\begin{array}{l}\text { - Empathy Practices } \\
\text { - Division of Labour }\end{array}$ & \\
\hline & - Collaboration Skills & \\
\hline & - Receiving Feedback & \\
\hline & - Sensing Others' & \\
\hline & Motives & \\
\hline & - Group Projects & \\
\hline \multirow[t]{13}{*}{ INTRAPERSONAL } & - Meditation Methods & - Personal choice \\
\hline & • Meta-cognition & software \\
\hline & Techniques & - Career counselling \\
\hline & - Thinking Strategies & software \\
\hline & - Emotional Processing & • Any self-paced \\
\hline & •"Know Thyself" & programme \\
\hline & $\begin{array}{l}\text { Procedures } \\
\text { - Mindfulness Practices }\end{array}$ & \\
\hline & - Focusing/Concentration & \\
\hline & Skills & \\
\hline & • Higher-Order & \\
\hline & Reasoning & \\
\hline & • Complex Guided & \\
\hline & $\begin{array}{l}\text { Imagery } \\
\text { •"Centring" Practices }\end{array}$ & \\
\hline
\end{tabular}


TABLE 5:

CONVENTIONAL MEDia

\begin{tabular}{|c|c|c|}
\hline PRINTED & 3D OBJECTS & AUDIO/VISUAL \\
\hline $\begin{array}{ll}\bullet & \text { Books } \\
\text { - } & \text { Encyclopaedias } \\
\text { - } & \text { Magazines } \\
\text { - } & \text { Newspapers } \\
\text { - } & \text { Documents } \\
\text { - } & \text { Flat Pictures } \\
\text { - } & \text { Drawings/Paintings } \\
\text { - } & \text { Maps } \\
\text { - } & \text { Graphs/Charts/ } \\
\text { - } & \text { Diagrams } \\
- & \text { Posters } \\
- & \text { Cartoons/Comics }\end{array}$ & $\begin{array}{ll}\bullet & \text { Globes } \\
\bullet & \text { Puppets } \\
\bullet & \text { Models } \\
\bullet & \text { Mock-ups } \\
\bullet & \text { Collections } \\
- & \text { Specimens }\end{array}$ & $\begin{array}{ll}\bullet & \text { Slide-Tapes } \\
\bullet & \text { Filmstrips } \\
\bullet & \text { Radio Programmes } \\
\bullet & \text { TV Programmes } \\
\bullet & \text { Motion-picture } \\
\bullet & \text { films } \\
\bullet & \text { Microfilms/ } \\
\bullet & \text { Microfiches } \\
\bullet & \text { Audio Cards } \\
\bullet & \text { Audio Tapes }\end{array}$ \\
\hline
\end{tabular}

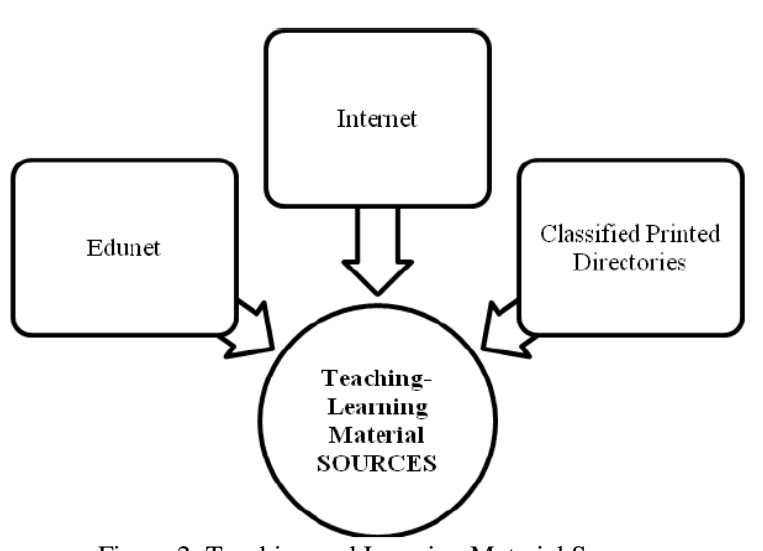

Figure 2: Teaching and Learning Material Sources

\section{REFERENCES}

[1] Anderson, L., \& Krathwohl, D. (2001). A taxonomy for learning, instructional, and assessing . Boston, MA: Allyn and Bacon.

[2] Armstrong, T. (2000). Multiple intelligences in the classroom $\left(2^{\text {nd }} e d\right.$.). Alexandria, VA: ASCD.

[3] Campbell, L., \& Campbell, B. (1999). Multiple intelligences and students achievement: Success stories from six schools. USA: Association for Supervision and Curriculum Development.

[4] Case, C., \& Truscott, D. (1999). The lure of bells and whistles: Choosing the best software to support reading instruction. Reading and Writing Quarterly: Overcoming Learning Difficulties, 15(4), 361-369.

[5] Gardner, H. (1993). Multiple Intelligences: The theory in practice. New York: Basic Books.

[6] Gardner, H. (2004). Frames of mind: The theory of multiple intelligences ( $2^{\text {nd }} e d$.). New York: Basic Books.

[7] Greenhawk, J. (1997). Multiple Intelligences meets standards. Educational Leadership ,55(1) 62-64.

[8] Kornhaber, M., Fierros, E., \& Veenema, S. (2003). Multiple intelligences: Best ideas from research and practice. In B. Shearer, MI at 25: Assessing the impact and future of multiple intelligences for instructional and learning. New York: Teachers College Press.

[9] Lewis, P. (1997). Using productivity software for beginning language learning Part 1. The word processor. Learning and Leading with Technology, 24(8), 14-17.

[10] Mckenzie, W. (2005). Multiple intelligences and instructional technology (2 $\left.2^{\text {nd }} e d.\right)$. Eugene, OR: International Society for Technology in Education.

[11] Ministry of Education. (1997). The Malaysian smart school: A conceptual blueprint. Kuala Lumpur: Author

[12] Rosen, D. (1997). Do technology based lessons meet the needs of student learning styles? Retrieved November 24, 2009, from http://editlib.org/index.cfm?...\&paper_id=25233.

[13] Saban, A. (2000). Toward a more intelligent school. Educational Leaderships, 60, 71-73.

[14] Shearer, B. (2009). MI at 25: Assessing the impact and future of Multiple Intelligences for teaching and learning. New York: Teachers College Press.

[15] Tomei, L.A. (2003). Challenges of instructional with technology across the curriculum: Issues and solutions. Hershey: Information Science Publishing.

[16] Yilmaz, G., \& Fer, S. (2003). The students' opinion and achievement concerning instructional activities based on multiple intelligences theory. Hacettepe Universitesi Egitim Fakultesi Dergisi, 25, 235-245.

Tajularipin Sulaiman Ph.D is currently a lecturer in Faculty of Educational Studies, University Putra Malaysia. received his early education in Muar, Johor and continued his secondary education at the Sekolah Teknik Malacca. He continued his studies at the 
Centre for Foundation Studies in Science, Universiti Malaya in 1998. He obtained the Bachelor of Science with Education Degree in 1994 and Master of Education in 1998 from the University Malaya. He holds a doctoral degree in education from University Putra Malaysia. His area of specialization is in pedagogy, science education, and cognitive development. He has involved in courses in science education, thinking skills and primary education. His research interests are in the fields of pedagogy and primary education especially in primary science. He has also presented papers in national and international conferences

Suriati Sulaiman is an English teacher at Temerloh Secondary School in Pahang. She obtained her Bachelor Degree at International Islamic University of Malaysia and currently pursuing her Master of Science in Curriculum and Instruction at University Putra Malaysia. She is a dedicative educator and has devoted herself in teaching field for more than 12 years. Her research interest areas are Instructional design, Intelligence and Language learning.

Wei Hui Suan is currently a Japanese Language lecturer in Centre for Foundation Studies and Extension Education (FOSEE), Multimedia University. She obtained her Bachelor of Arts and Letters from Tohoku University, Japan in 2004 and pursued her Master in University Putra Malaysia in the field of Educational Psychology and graduated in 2008. She is an experience educator with a total of more than 16 years experience in language teaching. Her research interests are in the fields of teaching and learning, educational Psychology, multiple intelligences, thinking skills and cognitive development. 